\title{
Zpráva z 15. setkání EBC 18.-19. ř́jna 2019 v Barceloně
}

\author{
Jan F. Vojáček \\ I. interní kardioangiologická klinika LF UK a FN, Hradec Králové \\ Kardiologie Bulovka, s. r. o., Praha
}

Již 15. setkání Evropského bifurkačního klubu (European Bifurcation Club - EBC) se konalo 18.-19. ríjna 2019 v Barceloně. Mezi klíčová témata, o nichž se diskutovalo, patriilo intrakoronární zobrazování a probíhající bifurkační registry. Tento dvoudenní meeting již tradičně klade velký důraz na teoretické studie ve formě experimentálních a výpočetně-simulačních prací. Součástí jednání je i hlasování a vytváření konsensuálního názoru na vybrané aktuální problémy.

Loňský meeting byl mimo jiné pozoruhodný i tím, že vzhledem k tehdejší aktuální politické situaci v Barceloně bylo pro řadu účastníků zrušeno letecké spojení do Barcelony, a proto všechna jednání probíhala současně on-line s možností aktivních vstupů přednáškami, diskuzí a hlasováním z domova po celém světě nebo prímo z katetrizačních laboratoří (obrázek 1).

$\checkmark$ sekci „Real-World Bifurcation Registries" byl predstaven prospektivní, multicentrický registr e-Ultimaster (Ultimaster DES Registry) a registry COBIS (Korean Coronary Bifurcation Stenting) I, II a III. Registr e-Ultimaster zahrnoval více než 37000 pacientů léčených ve více než 376 centrech v 50 zemích na čtyřech kontinentech. Prokázal, že „provisional stenting"zůstává dominantní strategií na celém světě v léčbě bifurkačních stenóz s vynikajícím střednědobým výsledkem, v registru byly použity stenty Ultimaster (Terumo). Strategie dvou stentů byla zaznamenána pouze u 21 \% nemocných. Tento registr také prokázal, že proximální optimalizace je spojena s významným prínosem z hlediska závažných nežádoucích kardiovaskulárních príhod (MACE) - bez ohledu na použitou strategii stentingu. Registr také prokázal, že techniky dvou stentů již nejsou spojeny s horšími výsledky při použití novější generace DES ve srovnání s první generací DES. Registr dále ukázal, že „kissing balloon“ technika je spojena s lepšími výsledky než pouhá dilatace boční větve.

Registry COBIS I, II a III byly podobné registru e-Ultimaster a souhrnné údaje z tohoto probíhajícího registru rovněž potvrdily, že převládající technikou u bifurkačních stenóz je „provisional one-stent strategy". Kromě toho se i zde ukázalo, že strategie dvou stentů prováděná pomocí DES nové generace již nemá nepříznivé výsledky strategií se dvěma DES první generace. Investigátoři COBIS proto doporučují začít u závažnějšího bifurkačního postižení (Medina $1,1,1)$ rovnou dvoustentovou strategií. V registru COBIS III nebyl žádný významný rozdíl mezi různými strategiemi dvou stentů (double kissing crush (DK Crush), Tand small protrusion a culotte).

Vedle registrů bifurkačních stenóz se velkému zájmu těšilo sdělení PW Serruyse o 15letém sledování nemocných ve studii SYNTAX a 10letém ve studii EXCEL. Profesor Serruys se soustředil na prezentaci Syntax skóre II, které vzniklo Coxovým modelem proporcionálních rizik kombinace anatomických a klinických proměnných pro predikci čtyřleté mortality v dlouhodobém sledování v uvedených studiích. Pozoruhodné výsledky přinesla analýza prognózy při nerespektování doporučené léčby na základě Syntax skóre II. Byla hodnocena konkordantní skupina, která podstou- pila doporučenou léčbu, a diskordantní skupina, která ve skutečnosti podstoupila opačnou léčbu (tj. stenting vs. CABG). Pro kmen ACS stoupla čtyřletá mortalita při doporučení CABG a provedené PTCA na 15,1 \% oproti 4,1\%, pokud byl skutečně proveden CABG. Desetiletá mortalita u nemocných s doporučením PTCA a provedené PTCA byla 23,3\%, ale pokud přes doporučení PTCA byl ve skutečnosti nemocný operován aortokoronárním bypasem - stoupla na 37,6\%.

Ze zobrazovacích metod byl hlavní důraz kladen na trojrozměrnou optickou koherentní tomografii (OCT), ta byla demonstrována prakticky ve všech sděleních. V léčbě bifurkací se ukázal její význam nejvíce pro správný „rewiring"bočních větví u strategie „provisional stenting". 3D OCT je důležité i při hodnocení ostiální restenózy r. circumflexus pro rozlišení klasické restenózy oproti endotelializaci strutů stentu překrývajících ostium této boční větve. Právě ponechání volných strutů přes boční větev se ukázalo jako významná známka zhoršené prognózy.

Základní experimentální výzkum a výpočetní simulace pomocí ultra počítačové tomografie umožnily lépe porozumět různým strategiím se dvěma stenty. Bylo demonstrováno, že nedostatečná expanze a malapozice vedou k vyššímu smykovému napětí, které bylo lineárně závislé na stupni malapozice. In vitro došlo k vyšší agregaci krevních destiček a tvorbě sraženin, když byly simulovány velké segmenty malapozice. Po proximální optimalizaci a zobrazením potvrzenou dostatečnou dilataci stentu, výpočetní model odhalil sniženou agregaci krevních destiček a lepší

KORESPONDENČNÍ ADRESA AUTORA:

prof. MUDr. Jan F. Vojáček, DrSc., FESC, FACC, vojacjan@fnhk.cz

I. interní kardioangiologická klinika LF UK a FN, Sokolská 581, 50005 Hradec Králové

Cit. zkr: Interv Akut Kardiol 2020; 19(2): 137-138 


\section{INFORMACE}

Obr. 1. Jednání probihalo nejen v kongresové mistnosti HESPERIA TOWER BARCELONA, ale z velké části i pres web, a to jak ze strany přednášejicich, tak i ze strany nemalé části účastníkü

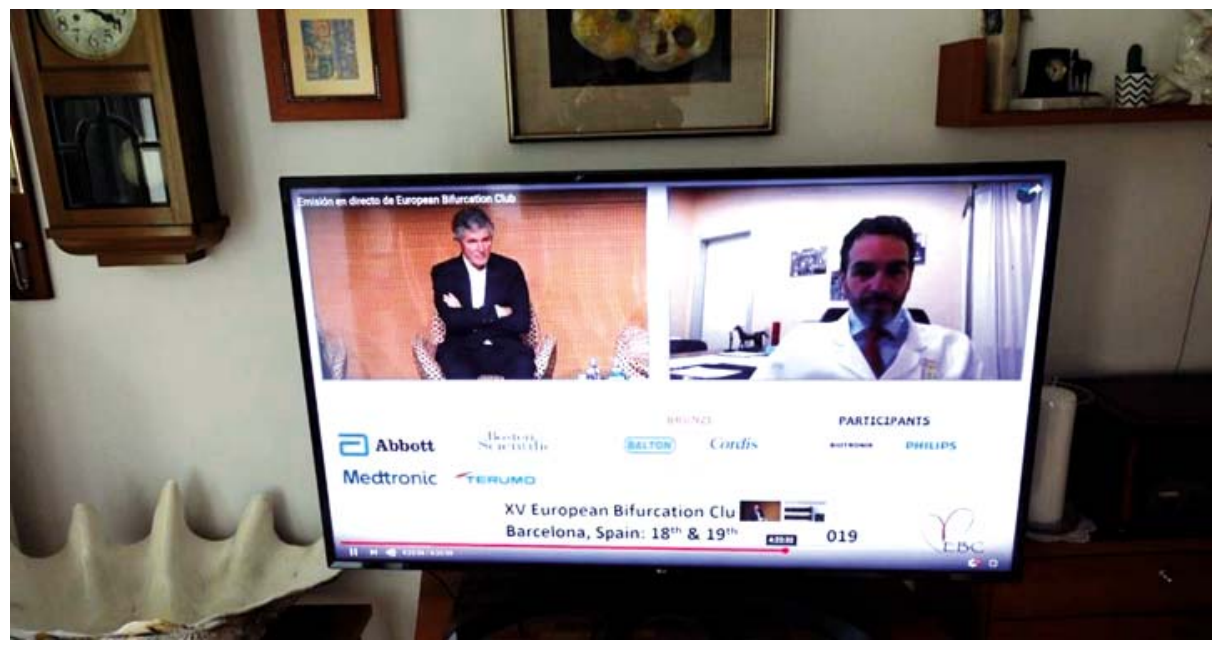

dynamiku toku. Tyto modely zdůraznily důležitost optimalizace a využití adekvátních zobrazovacích metod. Inženýři vysvětlili, že s vhodnou post-dilatací (rozšiření stentu na limity výrobce) se radiální síla zvyšuje a recoil snižuje u ultratenkých stentů nové generace.

Tradiční blok nejaktuálnějších kontroverzí bifurkačního stentingu v posledních letech po- mocí hlasování po předchozích souhrnech pro a proti prováděných předními experty vyjadřuje konsensuální stanovisko k následujícím otázkám. V letošním roce bylo umožněno hlasování pomocí aplikace sli.do i těm účastníkům, kteří nebyli fyzicky prítomni, ale byli připojeni on-line.

Většina hlasů účastníků vedla k následujícím názorům:
- Izolovaná ostiální postižení levé přední sestupné větve nebo levého ramus circumflex nemohou být přesně stentována bez rizika restenózy v tomto místě, ostiu druhé větve, nebo distální cásti kmene levé věnčité tepny. Stenting by se proto měl rozširirit z cévy s ostiální stenózou do kmene levé věnčité tepny s konečnou proximální optimalizací kmene.

- Při „provisional" stentingu s prekrytím odstupu velké boční větve bez významné stenózy vede dilatace boční větve přes oko stentu ke zvýšené frekvenci ostiální restenózy boční větve a neměla by být prováděna. Proximální optimalizace stentu v hlavní větvi je dostatečná. Důležité jsou „final kissing inflations" při „provisional strategy”.

- Pro komplexní bifurkační stenózu, kde se použivá strategie se dvěma stenty, je upřednostňována technika Crush (DK Crush).

- Bez ohledu na strategii (DCB nebo ne, ,provisional" nebo "two-stent"), kmen levé věnčité tepny nebo jiné bifurkace, zůstává ideální doba trvání duální antiagregační léčby pro bifurkace v tuto chvíli neznámá 